\title{
Mass Spectrometry Characterization of the Thermal Decomposition/Digestion (TDD) at Cysteine in Peptides and Proteins in the Condensed Phase
}

\author{
Franco Basile, Shaofeng Zhang, Sujit Kumar Kandar, Liang Lu \\ Department of Chemistry, University of Wyoming, 1000 University Ave., Laramie, WY 82071, USA
}

\begin{abstract}
We report on the characterization by mass spectrometry (MS) of a rapid, reagentless and sitespecific cleavage at the N-terminus of the amino acid cysteine $(C)$ in peptides and proteins induced by the thermal decomposition at $220-250{ }^{\circ} \mathrm{C}$ for $10 \mathrm{~s}$ in solid samples. This thermally induced cleavage at $\mathrm{C}$ occurs under the same conditions and simultaneously to our previously reported thermally induced site-specific cleavage at the C-terminus of aspartic acid (D) (Zhang, S.; Basile, F. J. Proteome Res. 2007, 6, (5), 1700-1704). The C cleavage proceeds through cleavage of the nitrogen and $\alpha$-carbon bond ( $\mathrm{N}$-terminus) of cysteine and produces modifications at the cleavage site with an amidation $(-1 \mathrm{Da})$ of the $\mathrm{N}$-terminal thermal decomposition product and a $-32 \mathrm{Da}$ mass change of the C-terminal thermal decomposition product, the latter yielding either an alanine or $\beta$-alanine residue at the $\mathrm{N}$-terminus site. These modifications were confirmed by off-line thermal decomposition electrospray ionization (ESI)-MS, tandem MS (MS/MS) analyses and accurate mass measurements of standard peptides. Molecular oxygen was found to be required for the thermal decomposition and cleavage at $\mathrm{C}$ as it induced an initial cysteine thiol side chain oxidation to sulfinic acid. Similar to the thermally induced $D$ cleavage, missed cleavages at $C$ were also observed. The combined thermally induced digestion process at $D$ and $C$, termed thermal decomposition/digestion (TDD), was observed on several model proteins tested under ambient conditions and the site-specificity of the method confirmed by MS/MS.
\end{abstract}

Key words: Protein thermal decomposition, Rapid protein digestion, Pyrolysis, Proteomics, Mass spectrometry, Tandem mass spectrometry

\section{Introduction}

$\mathrm{P}$ yrolysis (thermal lysis) has historically been used for the rapid preparation of samples for mass spectrometry

Electronic supplementary material The online version of this article (doi:10.1007/s13361-011-0222-9) contains supplementary material, which is available to authorized users.

Correspondence to: Franco Basile; e-mail: basile@uwyo.edu
(MS) analysis. Pyrolysis is defined as the decomposition reactions caused by thermal energy alone at temperatures above $300-350{ }^{\circ} \mathrm{C}$, while reactions caused by thermal energy at temperatures between $175-250{ }^{\circ} \mathrm{C}$ are considered thermal decompositions [1]. (Note: in previously published work from our laboratory, we have referred to all these processes as pyrolysis, for example, pyrolysis D-cleavage for the thermally induced cleavage at aspartic acid (D) [2]. However, in view of Moldoveanu's definitions of pyrolysis and thermal decomposition [1], we adopt in this manuscript 
the convention of referring to reactions conducted at temperatures between $150-300{ }^{\circ} \mathrm{C}$ as thermal decompositions, rather than pyrolysis). As a MS inlet, direct insertion probes (DIP) and/or pyrolysis have been used to analyze high molar mass samples by generating low molecular weight volatile molecules (i.e., thermal fragments) that are more amenable for analysis by electron ionization (EI) MS. Samples analyzed in this mode included high molecular weight synthetic polymers $[3,4]$, biomolecules $[5,6]$, and intact microorganisms [7-10]. Useful information regarding the monomer constituents in synthetic polymers could be obtained from mass spectra generated from these volatile thermal fragments. In the case of analysis of biological samples, the information yielded by these measurements was more limited due to the high complexity of the sample and the resulting mass spectra. Implementation of pattern recognition data analysis like principal components analysis (PCA) $[11,12]$ aided in the classification of complex mass spectral patterns with subtle differences between them. This strategy proved particularly successful for the classification of micro-organisms based on their mass spectral lipid profiles [13]. However, because DIP and/or Pyrolysis-MS was usually performed using EI, the measurement was limited to the analysis of volatile pyrolysis products of molar masses below about $1000 \mathrm{~g} / \mathrm{mol}$.

With the advent of electrospray ionization (ESI) [14-16] and matrix assisted laser desorption ionization (MALDI) [17-20], the analysis of high molar mass molecules was made possible and opened the possibility to analyze nonvolatile products of thermal decompositions. Latimer et al. $[21,22]$ first applied MALDI-MS for the analysis of nonvolatile pyrolysis products of synthetic polymers, detecting several species corresponding to the original polymer backbone. Meetani et al. later analyzed the nonvolatile thermal decomposition products $\left(245^{\circ} \mathrm{C}\right)$ of a series of poly-peptides with MALDI-MS, again detecting a series of high molecular mass products [23], the distribution of these products depending on the nature of the amino acids present in the peptide sequence. In a more recent study implementing LC-MS/MS, Meetani et al. also reported that thermal decomposition products of the leuenkephalin peptide resulted from a sequence ladder fragmentation through the formation of head-to-tail cyclic peptide fragments (and consequently with a -18 Da shift) [24]. Using a combination of MS and tandem MS (MS/MS) for the analysis of nonvolatile thermal decomposition products of peptides and proteins, our laboratory discovered that a site-specific fragmentation occurred at the C-terminus of aspartic acid (D) when peptides or proteins were subjected to temperatures between 200 and $250^{\circ} \mathrm{C}$ for $10 \mathrm{~s}[2,25]$. The products of the thermal cleavage at $\mathrm{D}$ were easily identified by mass alone since these products resulted from a hydrolysis of the peptide bond Cterminus of D. Other products also detected corresponded to water and ammonia losses. Our study also demonstrated that peptides formed through the thermal decomposition of large proteins (e.g., lysozyme) preserved the sequence information of the original protein, and implementing a bottom-up proteomic approach (MS/MS measurement and database matching) a standard protein sample was identified from a peptide resulting from the thermal decomposition site-specific cleavage at D alone (using MASCOT MS/MS Ions Search) [2].

Combined, these results point to the possibility of using thermal decomposition reactions in proteins as a rapid sitespecific protein digestion technique when detecting nonvolatile products. Towards this goal, this study presents evidence of another site-specific thermally induced cleavage in peptides and proteins at the N-terminus of the amino acid cysteine (C), which occurs concurrently with the thermally induced cleavage at $\mathrm{D}$. The combined thermally induced cleavages at $\mathrm{D}$ and $\mathrm{C}$, here termed thermal decomposition/ digestion (TDD), were observed under the same experimental conditions (atmospheric conditions, $\mathrm{T}_{\max }=220{ }^{\circ} \mathrm{C}$ for $10 \mathrm{~s}$ ). Unlike the thermally induced cleavage at $\mathrm{D}$, the thermally induced cleavage at $\mathrm{C}$ is accompanied by mass changes at the cleavage site of both the $\mathrm{C}$ - and $\mathrm{N}$-terminal products. As a result of these mass changes (i.e., not resulting from a peptide bond hydrolysis), the cleavage at $\mathrm{C}$ remained undiscovered in our previous work describing the cleavage at $\mathrm{D}[2]$. Using a series of standard peptides and a ${ }^{15} \mathrm{~N}$-stable isotope peptide, studies were performed with MS/MS and accurate mass measurements to confirm the cleavage site at $C$, the mass changes and nature of the observed products after the thermal cleavage under atmospheric conditions of peptides containing the amino acid $\mathrm{C}$.

\section{Experimental}

\section{Chemicals}

Peptides used were: (1) $\mathrm{PHC}_{\mathrm{ox}} \mathrm{KRM}$, where $\mathrm{C}_{\mathrm{ox}}$ is the $\mathrm{C}$ side chain oxidized to a sulfonic acid; (2) antioxidant peptide A, sequence PHCKRM; (3) somatostatin14, sequence AGCKNFFWKTFTSC; (4) AWRG $\left({ }^{15} \mathrm{~N}\right)$ CLLFK all from AnaSpec (San Jose, CA). The peptide AWRG-NH $\mathrm{N}_{2}$ was purchased from American Peptide Co. (Sunnyvale, CA). The peptide of sequence AWRGCLLFK was synthesized using standard fluorenylmethyloxycarbonyl (FMOC) solid-phase synthesis on a PS-3 automated peptide synthesizer (Proteins Technologies, Inc.). The synthetic peptide was purified by reverse-phase HPLC and sample purity was verified by MALDI-MS. The proteins $\alpha$-lactalbumin (bovine milk, FW $14.2 \mathrm{kDa}$ ) and lysozyme (chicken egg white, FW $14.3 \mathrm{kDa}$ ) were all from Sigma (St. Louis, MO) and used without further purification. The MALDI matrix $\alpha$-cyano-4-hydroxycinnamic acid (CHCA) was from Sigma and used without further purification. All solvents [water, methanol, acetonitrile $(\mathrm{ACN})]$ used for sample preparation and MS measurements were HPLC grade (Burdick and Jackson, Muskegon, MI), trifluoroacetic acid (TFA; Pierce Chemical Company, Rockford, IL), and the formic acid (FA 96\%) were ACS reagent grade (Aldrich, St. Louis, MO). 


\section{Pyrolyzer Design and Thermal Decomposition/ Digestion (TDD) Procedure of Peptides and Proteins}

Thermal Decomposition/Digestion (TDD) of peptides and proteins were conducted using a home-built pyrolyzer device [2]. Briefly, the pyrolyzer consisted of a glass tube (length $31 \mathrm{~mm}$ and internal diameter $4 \mathrm{~mm}$; Agilent, Santa Clara, CA; part no. 5180-0841) and a resistance heating wire (Omega, Stamford, CT, Nickel-Chromium wire; part no. NI60-015-50, length $20 \mathrm{~cm}$ ) enwound around the tube. The pyrolyzer was heated by powering the resistance heating wire with alternating current (AC) from a transformer (model no. 3PN116C; Superior Electric, Farmington, CT). Temperature was measured in situ using a thermocouple probe (model HH12A; Omega Company, Stamford, CT) reaching down to the bottom of the glass tube. Approximately a $1 \mathrm{mg}$ solid sample of the peptide or protein was placed in the pyrolyzer tube and was heated for $10 \mathrm{~s}$ under ambient conditions to a final temperature of $220^{\circ} \mathrm{C}$. This corresponded to an $\mathrm{AC}$ voltage of approximately $13 \mathrm{~V}$; however, final temperature (and as a result, applied voltage) depends highly on the pyrolyzer design and, thus, on the heat capacity of the pyrolyzer device. The heating time was controlled by an electronic digital timer (Gra-lab, model 655; Centerville, $\mathrm{OH}$ ). After heating, the TDD nonvolatile residue was collected by washing/extracting the inside of the tube with several fractions totaling $1 \mathrm{~mL}$ of $50 / 50(\mathrm{vol} / \mathrm{vol})$ methanol/ $/ 0.1 \%$ formic acid (FA) aqueous solution. This solution was used directly for ESIMS and/or MALDI-MS analyses.

The TDD process was also performed, in addition to laboratory atmospheric conditions (i.e., air), under different controlled atmospheres using $\mathrm{N}_{2}, \mathrm{NH}_{3}, \mathrm{O}_{2}$, or $\mathrm{O}_{2}+\mathrm{NH}_{3}$ gasses. Controlled atmospheric thermal decomposition experiments were performed with the furnace pyrolyzer described above enclosed inside a $20 \mathrm{~mL}$ glass vial, the latter fitted with a septum stopper and side holes for connections to the heating wire. The atmosphere inside the glass vial was flushed with the corresponding gas for about 2 min before heating. About $0.2 \mathrm{mg}$ of the peptide antioxidant A (Sequence: PHCKRM) was used for all of the controlled atmosphere experiments. The tube was heated to a maximum temperature of $220^{\circ} \mathrm{C}$ (the applied voltage was adjusted to achieve the desired maximum temperature in order to account for the gasses different thermal conductivities). A total of five replicate samples were performed for each gas.

\section{Mass Spectrometry}

The extracted solution of the TDD nonvolatile products were analyzed by direct infusion into a quadrupole ion-trap MS (LCQ classic, Thermo Finnigan, San Jose, CA) equipped with a micro-electrospray ionization (ESI) source. The sample was infused into the mass spectrometer at a flow rate of $3 \mu \mathrm{L} / \mathrm{min}$ via a $250-\mu \mathrm{L}$ syringe (Hamilton, Holliston, MA) using the built-in LCQ syringe pump. The mass spectra were collected using the $\mathrm{LCQ}^{\mathrm{TM}}$ Tune Plus software (Thermo Finnigan, San Jose, CA). Tandem MS (MS/MS) using collision induced dissociation (CID) was conducted with the following parameters: activation q of 0.250 ; isolation width was $1 \mathrm{Da}$ and the percentage relative collision energy was in the range of $25 \%-40 \%$, and was adjusted such that the relative abundance of the precursor ion in the product ion spectrum was approximately $30 \%-50 \%$ relative intensity.

MALDI-MS experiments were performed using either a Voyager DE-PRO or DE-STR (Applied Biosystems, Foster City, $\mathrm{CA}$ ) instrument equipped with a $\mathrm{N}_{2}$ laser and operated in the reflectron mode. The matrix $\alpha$-cyano-4-hydroxycinnamic acid (CHCA) was used for all measurements and was prepared by dissolving $10 \mathrm{mg}$ of CHCA in a $1 \mathrm{~mL}$ solution of $1: 1$ acetonitrile/ $0.1 \%$ TFA aqueous solution. The solution containing the extracted TDD products was directly mixed with the matrix at different volume ratios, deposited (approximately $0.2 \mu \mathrm{L}$ ) and air-dried onto a MALDI plate. All MALDI-mass spectra were internally calibrated with either the intact peptide signal and/or a known TDD product peptide after its sequence was confirmed by ESI-MS/MS.

Accurate mass data were acquired using a hybrid linear ion trap/7-T Fourier transform (FT)-ion cyclotron resonance (ICR) MS (LTQ-FT; Thermo Electron, Bremen, Germany) equipped with a micro spray ion source (University of Utah Mass Spectrometry and Proteomics Core Facility). The ESI voltage, capillary voltage, capillary temperature and tube lens were set at $2.8 \mathrm{kV}, 47 \mathrm{~V}, 175{ }^{\circ} \mathrm{C}$, and $150 \mathrm{~V}$, respectively. The sheath gas $\left(\mathrm{N}_{2}\right)$ pressure was 50 psi with an auxiliary gas $\left(\mathrm{N}_{2}\right)$ flow of 10 units. Peptides were analyzed in the positive ion mode. Peptides were dissolved in a solvent mixture of $50 \% \mathrm{ACN} / 0.1 \%$ aqueous $\mathrm{FA}$ and infused into the instrument at $3 \mu \mathrm{L} / \mathrm{min}$ flow rate. The FTMS was operated with a 50,000 resolution in the ICR cell. Accurate mass measurements were acquired using peptide internal standards. The peptides MRFA, FGFG, Angiotensin-III, YGGFM, YGGFLK, and YGGFL were used as internal standards. Internal standards were purchased from Sigma-Aldrich and used without further purification.

\section{Results and Discussion}

Several peptide and protein standards were thermally decomposed at temperatures ranging between $220-240{ }^{\circ} \mathrm{C}$ and the nonvolatile products analyzed by a combination of ESI-MS, ESI-MS/MS, and MALDI-MS. Investigations were first carried out on low molar mass peptides in order to simplify interpretation of the resulting mass spectra, followed by a study involving high molar mass protein standards. The terminology used to describe the thermal degradation fragments is illustrated in Scheme 1, where N-terminal and C-terminal TDD products refer to the (neutral) product that retains either the $\mathrm{N}$ or C-terminus of the precursor peptide, respectively.

In order to implement the TDD approach as a protein digestion technique in proteomics, accurate knowledge of the chemical composition of the cleavage products is 


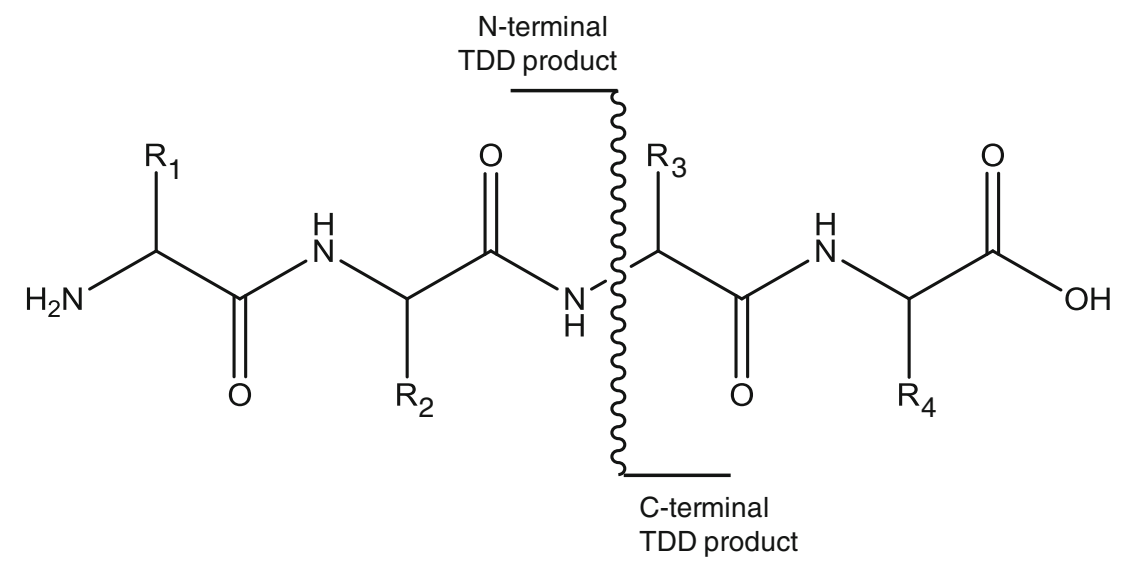

Scheme 1. Terminology used to describe the thermal degradation products in peptides

required. Because the thermal decomposition cleavage at $\mathrm{C}$ involves mass changes of both $\mathrm{C}$ - and $\mathrm{N}$-terminal cleavage products, accurate mass measurements were performed on the C-terminal TDD product. Moreover, the TDD products of a stable-isotope-labeled peptide were analyzed by MS and MS/MS in order to elucidate the most likely structure of the products and the mechanism of fragmentation.

\section{Thermal Decomposition/Digestion (TDD) of Peptides}

The peptide with the amino acid sequence PHCKRM was heated under atmospheric conditions at $220{ }^{\circ} \mathrm{C}$ for $10 \mathrm{~s}$ using the tube furnace pyrolyzer. The nonvolatile thermal decomposition products were extracted and analyzed by direct infusion ESI-MS and the resulting mass spectrum is shown in Figure 1a. The intact peptide protonated molecule, $[\mathrm{MH}]^{+}$, is observed at $m / z 771.4$, as well as ions corresponding to the loss of water $(\mathrm{m} / \mathrm{z}$ 753.4) and consecutive losses of ammonias $(\mathrm{m} / \mathrm{z} 737.4)$. The ion at $\mathrm{m} / z 505.5$ is attributed to the peptide ${ }^{-32} \mathrm{CKRM}$ resulting from the cleavage at the $\mathrm{N}$ terminus of $\mathrm{C}$ with an observed mass change of $-32 \mathrm{Da}$ (denoted by the left superscript -32 in $\mathrm{C}$, that is, ${ }^{-32} \mathrm{C}$ in the sequence). This mass change is relative to the expected $\mathrm{m} / \mathrm{z}$ 537.26 (not observed) for the $[\mathrm{MH}]^{+}$ion of the peptide with the same amino acid sequence that would result from a hydrolysis cleavage of the peptide bond $\mathrm{N}$-terminus to $\mathrm{C}$. The signal corresponding to the $[\mathrm{MH}+96]^{+}$ion at $\mathrm{m} / z 867.4$ corresponds to the substitution of the C-terminus hydroxyl group with a trifluoroacetate group during the heating process (residual trifluoroacetic acid is present in most of these peptide samples from the LC purification step). To confirm the mass shift and sequence assignment of the ion at $m / z 505.5$, tandem MS (MS/ MS) was performed and the resulting tandem mass spectrum is shown in Figure 1b. Signals corresponding to b-ions $\left(b_{2}, b_{3}\right.$, and $\left.\mathrm{b}_{4}\right)$ and a y-ion $\left(\mathrm{y}_{2}\right)$ of the proposed sequence (and modification) were observed, as well as ions corresponding to losses of ammonia and water. From this tandem mass spectrum it can be noted that signals corresponding to $b$-ions are shifted by $-32 \mathrm{Da}$ (from the unmodified fragment ion), indicating that the assumed modification most likely occurs at the $\mathrm{N}$-terminus of the peptide. Also observed were ions corresponding to internal scrambled sequence at $m / z 175.1\left({ }^{*} \mathrm{y}_{1}\right)$ and $374.3\left({ }^{*} \mathrm{y}_{3}\right)$, due to the known cyclization of the precursor ion during the CID process [26-30], and correspond to the permutated sequence $\mathrm{M}^{-32} \mathrm{CKR}$, which includes the modified $\mathrm{C}$ residue.

To gather further evidence for the thermal decomposition cleavage at $\mathrm{C}$ and possible modification(s) to the $\mathrm{N}$-terminal thermal decomposition product (not observed in Figure 1a), the peptide somatostatin (sequence AGCKNFFWKTFTSC) was thermally degraded under similar conditions and analyzed by ESI-MS. This peptide contains two $\mathrm{C}$ in its sequence (C-3 and C-14), providing more opportunities to observe the mass changes produced by the thermal decomposition process. The ESI-mass spectrum of the nonvolatile thermal decomposition products is shown in Figure 2a. The product due to thermal cleavage at the $\mathrm{N}$-terminus of both $\mathrm{C}$ sites (C-3 and C-14) was observed at $m / z 1375.7$ (and its sodiated ion at $\mathrm{m} / \mathrm{z} 1397.8)$ as well as the missed cleavage product (missed cleavage at C-3) at $\mathrm{m} / \mathrm{z}$ 1535.6. These products illustrate the mass changes induced by the thermal decomposition process at the $\mathrm{N}$ - and $\mathrm{C}$-termini of the $\mathrm{C}$ cleavage site: $-32 \mathrm{Da}$ at the $\mathrm{C}$-terminus of $\mathrm{C}$ and $-1 \mathrm{Da}$ at the N-terminus of $\mathrm{C}$ (the latter indicated by the left superscript of -1 on the amino acid, that is, ${ }^{-1} \mathrm{X}$, where $\mathrm{X}$ is any amino acid $\mathrm{N}$-terminus to the $\mathrm{C}$ in the parent peptide). These combined mass changes are best illustrated with the thermal decomposition product at $m / z 1375.7$, where C-3 is modified by -32 Da and S-13 (N-terminus to C-14) is modified by $-1 \mathrm{Da}$. Sequence confirmation of the products at $\mathrm{m} / \mathrm{z} 1535.6$ and 1375.6 was performed by MS/MS analysis and the results are shown in Figure $2 b$ and $c$, respectively. In Figure $2 b$ the tandem mass spectrum of the ion at $m / z 1535.6$ shows signals corresponding to $\mathbf{b}$-ions, $\boldsymbol{b}_{7}$ through $b_{13}$, of the proposed sequence, which account for the $-1 \mathrm{Da}$ mass modification at the $\mathrm{N}$-terminus of the peptide. Particularly prominent in this product ion mass spectrum is the ion at $\mathrm{m} / \mathrm{z} 1518.5$ corresponding to either $\mathrm{NH}_{3}$ loss from the C-terminus amide or $\mathrm{NH}_{3}$ loss from a lysine side chain. Also observed in this product ion mass 

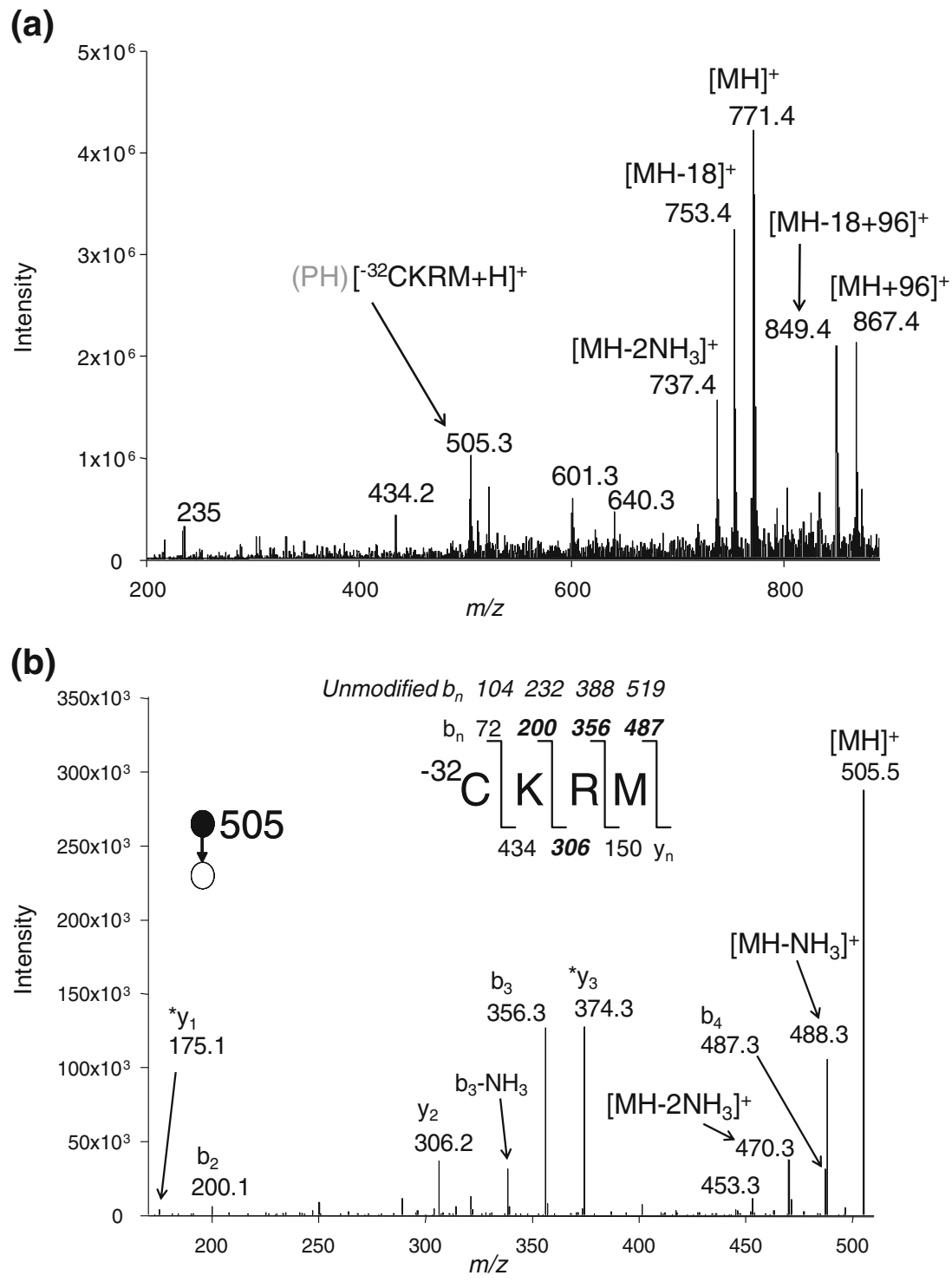

Figure 1. (a) ESI-mass spectrum of the nonvolatile thermal decomposition (TD; $220{ }^{\circ} \mathrm{C}, 10 \mathrm{~s}$ ) products of the peptide PHCKRM, (b) tandem mass spectrum of the thermal decomposition product at $\mathrm{m} / \mathrm{z} 505.5$. lons labeled $\mathrm{y}^{\star}$ are the product of sequence permutation due to ion cyclization during the CID process (see text for details), while $\mathrm{m} / \mathrm{z}$ values in bold in the fragmentation scheme denote that the ions were observed

spectrum are minor peaks corresponding to further $\mathrm{NH}_{3}$ losses from the ions $b_{12}$ and $b_{11}$. Since these ions already have lost the C-terminus amino acids, it is most likely that these $\mathrm{NH}_{3}$ losses are from the $\mathrm{K}$ side group. On the other hand, the $\mathrm{NH}_{3}$ loss to form the $\mathrm{b}_{13}$ ion at $m / z 1518.5$ is most likely due to a $\mathrm{NH}_{3}$ loss from a C-terminus amide. However, no $y$-ion series were observed in the product ion mass spectrum of this peptide to further confirm this rationalization. In Figure 2c the tandem mass spectrum of the ion at $\mathrm{m} / \mathrm{z} 1375.6\left({ }^{-32} \mathrm{CNFFWKTFT}^{-1} \mathrm{~S}\right)$ shows signals corresponding to both y-ion and b-ion series, which also take into account mass modifications at both thermally induced cleavage sites. All detected signals corresponding to b-ions are shifted by $-32 \mathrm{Da}$ (from an unmodified fragment), again indicating that the observed chemical modification most likely occurs towards the N-terminus of the peptide. Likewise, signals corresponding to y-ions are shifted by $-1 \mathrm{Da}$ and it is in agreement with a modification at the C-terminus of the product peptide and the proposed sequence. Combined, these results confirm that the thermal decomposition cleavage at $\mathrm{C}$ occurs at its $\mathrm{N}$-terminus and with chemical modifications at both the $\mathrm{C}$-terminus of the product peptide and on the N-terminus of the cysteine-containing peptide. Also, these data point to the most likely formation of an amide on the C-terminus of the product peptide. However, no conclusions can be drawn from these results as to where the cleavage is taking place, that is, at the peptide bond (carbonyl carbon-nitrogen bond, $\mathrm{CO}-\mathrm{N}$ ) or at the nitrogen- $\alpha$ carbon bond $\left(\mathrm{N}-\mathrm{C}_{\alpha}\right) \mathrm{N}$-terminus to C. Experiments incorporating stable isotopes and accurate mass measurements 

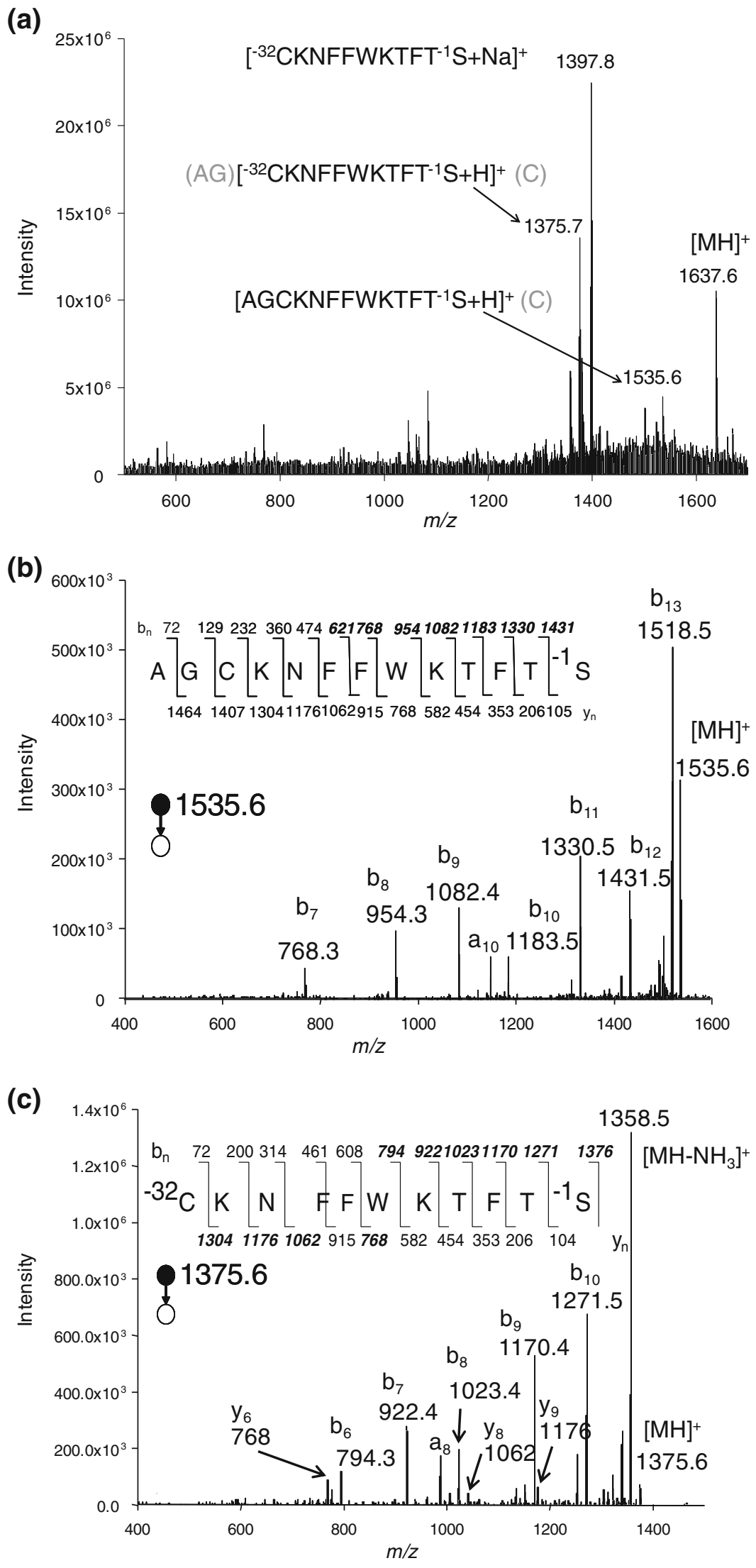

Figure 2. (a) ESI-mass spectrum of the nonvolatile thermal decomposition (TD; $220{ }^{\circ} \mathrm{C}, 10 \mathrm{~s}$ ) products of the peptide somatostatin (sequence AGCKNFFWKTFTSC), (b) tandem mass spectrum of the thermal decomposition product at $m / z$ 1535.6, (c) tandem mass spectrum of the thermal decomposition product at $\mathrm{m} / \mathrm{z} 1375.6$ 
were conducted to elucidate the most likely structure of the products and cleavage mechanism for the thermal decomposition cleavage at $\mathrm{C}$.

\section{Characterization of the Thermal Decomposition $N$-terminal Product of Peptides}

The -1 Da mass change in the N-terminal peptide product can be attributed to: (1) C-terminus amide formation, and (2) allysine (aminoadipic semialdehyde) from the oxidation of lysine [31]. Even though amidation is the most common modification resulting in a -1 Da mass change, modification of lysine during the heating process cannot be ruled out since $\mathrm{K}$ is present in somatostatin (Figure 2) and the same $\mathrm{m} / \mathrm{z}$ values of the b-ions detected could also be attributed to the presence of allysine in the sequence. In order to gather conclusive evidence about the nature of the -1 Da mass shift in the $\mathrm{N}$-terminus fragment to $\mathrm{C}$ and the nature of the fragmentation, a peptide with sequence AWRGCLLFK incorporating a nitrogen-15 $\left({ }^{15} \mathrm{~N}\right)$ stable isotope adjacent to the $\alpha$-carbon $\left({ }^{15} \mathrm{~N}-\mathrm{C}_{\alpha}\right.$, Scheme 2$)$ of the amino acid $\mathrm{C}$ was tested in a similar fashion.

Using this peptide, observation of a +1 Da shift in the $\mathrm{m} / \mathrm{z}$ value of either the $\mathrm{N}$-terminal or $\mathrm{C}$-terminal thermal decomposition product would indicate retention of the ${ }^{15} \mathrm{~N}$ adjacent to the $\alpha$-carbon in C. Moreover, retention of the ${ }^{15} \mathrm{~N}$ by the $\mathrm{N}$-terminus thermal decomposition product would provide evidence for the formation of an amide. The corresponding peptide containing an unlabelled nitrogen atom at $\mathrm{C}$ was also tested for comparison. Figure 3 shows the ESI-mass spectra of the nonvolatile thermal decomposition products for the unlabeled (Figure 3a) and ${ }^{15} \mathrm{~N}-\mathrm{C}_{\alpha} \mathrm{C}$ labeled (Figure 3b) peptides. The ion at $\mathrm{m} / \mathrm{z} 488.4$ in Figure $3 \mathrm{a}$ can be assigned to the $\mathrm{N}$-terminal thermal decomposition cleavage product of sequence $\mathrm{AWR}^{-1} \mathrm{G}$, where the $\mathrm{C}$-terminus $\mathrm{G}$ has a -1 Da mass change. For the ${ }^{15} \mathrm{~N}$-labeled peptide, the ESI-mass spectrum of the thermal decomposition products is shown in Figure $3 \mathrm{~b}$ and shows an ion at $\mathrm{m} / \mathrm{z} 489.4$, which corresponds to a $+1 \mathrm{Da}$ shift from the unlabelled peptide shown in Figure 3a, with no other $\mathrm{m} / \mathrm{z}$ values shifted by +1 observed. Consequently, results from these data can be rationalized by the formation of a Cterminus amide in the $\mathrm{N}$-terminal thermal decomposition product by cleavage of the ${ }^{15} \mathrm{~N}-\mathrm{C}_{\alpha}$ bond of $\mathrm{C}$, which<smiles></smiles>

Scheme 2. General structure of the ${ }^{15} \mathrm{~N}$ labeled cysteinecontaining peptide incorporates the ${ }^{15} \mathrm{~N}$ atom into the $\mathrm{N}$-terminal thermal decomposition product.

Further confirmation about the nature of the TD Nterminal product was gathered through MS/MS analyses of the unlabeled and ${ }^{15} \mathrm{~N}$-labeled thermal decomposition products, and of an amidated standard peptide of the same sequence, and their product ion mass spectra (of ions at $\mathrm{m} / \mathrm{z}$ 488 and 489) are shown in Figure 4a, b, and c, respectively. A quick survey of these product ion mass spectra shows that the fragmentation pattern and relative peak intensities are similar for these peptides; however, with several notable ions shifted by $+1 \mathrm{Da}$ in the ${ }^{15} \mathrm{~N}$-labeled peptide in Figure 4c. For example, the ions at $\mathrm{m} / \mathrm{z}$ 471.1, 453.3, 231.0, and 214.1 in the non-labeled thermal decomposition product peptide (Figure 4a) are observed shifted by $+1 \mathrm{Da}$ in the ${ }^{15} \mathrm{~N}$-labeled peptide product ion mass spectrum (ions at $\mathrm{m} / \mathrm{z}$ 472.3, 454.2, 232.0, and 215.1, respectively, in Figure 4c). The ion at $\mathrm{m} / \mathrm{z} 471$ in Figure 4a corresponds to the loss of $-17 \mathrm{Da}$, or a loss of ammonia $\left(\mathrm{NH}_{3}\right)$, and in this case this loss can result from the $\mathrm{C}$-terminus amide or from the arginine (R) side chain [32]. For an amide peptide, the $\mathrm{b}_{4}$ ion would involve the loss of $\mathrm{NH}_{3}$ from the C-terminus and this ion would be of the same $\mathrm{m} / \mathrm{z}$ value $(\mathrm{m} / \mathrm{z} 471)$ for both the unlabeled and labeled peptides. Figure $4 \mathrm{c}$ shows a strong signal at $\mathrm{m} / \mathrm{z} 472$ for the ${ }^{15} \mathrm{~N}$-labeled peptide, indicating that the loss of $\mathrm{NH}_{3}(-17 \mathrm{Da})$ from the $\mathrm{R}$ side chain is favored over the loss of ${ }^{15} \mathrm{NH}_{3}(-18 \mathrm{Da}$ ) from the C-terminus amide. In Figure $4 \mathrm{a}$ a small contribution from the loss of $-18 \mathrm{Da}$ is also observed at $m / z 470$ and it is most likely attributed to a previously observed dehydration product during the CID of peptides involving peptide backbone oxygens [32, 33]. Also shifted by $+1 \mathrm{Da}$ in the product ion mass spectrum of ${ }^{15} \mathrm{~N}$ labeled peptide is the ion at $\mathrm{m} / \mathrm{z}$ 454.2. This ion can be rationalized by consecutive losses of $\mathrm{NH}_{3}$ (side chain $\mathrm{R}$ ) and $\mathrm{H}_{2} \mathrm{O}$ (backbone oxygen) and/or C-terminus ${ }^{15} \mathrm{NH}_{3}$. In the unlabeled peptide product ion mass spectrum (Figure 4a) this consecutive losses yields an ion at $\mathrm{m} / \mathrm{z}$ 453.2. A small contribution from the consecutive losses of $\mathrm{R}$ side chain $\mathrm{NH}_{3}$ and C-terminus $\mathrm{NH}_{3}$ is also observed at $m / z 454$ in Figure 4a. This last observation indicates that the observed $-18 \mathrm{Da}$ loss in the labeled peptide (Figure 4c) is most likely due to dehydration via backbone oxygen [33], with a small contribution from the loss of ${ }^{15} \mathrm{NH}_{3}$ from the C-terminus. Key indicators of the presence of an amidated peptide resulting from the thermal decomposition cleavage at the $\mathrm{N}$ terminus of $\mathrm{C}$ are the fragment ions $\mathrm{y}_{2}$ and $\mathrm{y}_{2}-\mathrm{NH}_{3}$ in Figure $4 \mathrm{a}$ and $\mathrm{c}$. The $\mathrm{y}_{2}$ ion in the unlabeled peptide product ion mass spectrum is detected at $\mathrm{m} / \mathrm{z} 231$ (Figure 4a), while in the labeled peptide product ion mass spectrum is detected at $\mathrm{m} / z$ 232. In addition to these ions, the $\mathrm{y}_{2}-\mathrm{NH}_{3}$ ions resulting from the loss of $\mathrm{NH}_{3}$ from the $\mathrm{R}$ side chain in both native and labeled peptides and are observed at $\mathrm{m} / z 214.1$ and 215.1 , respectively. Finally, the thermal decomposition product (Figure 4a) and the standard amidated peptide (Figure 4b) product ion mass spectra are very similar, with all major peaks matching in $\mathrm{m} / \mathrm{z}$ value and intensity. Collectively, these data are 


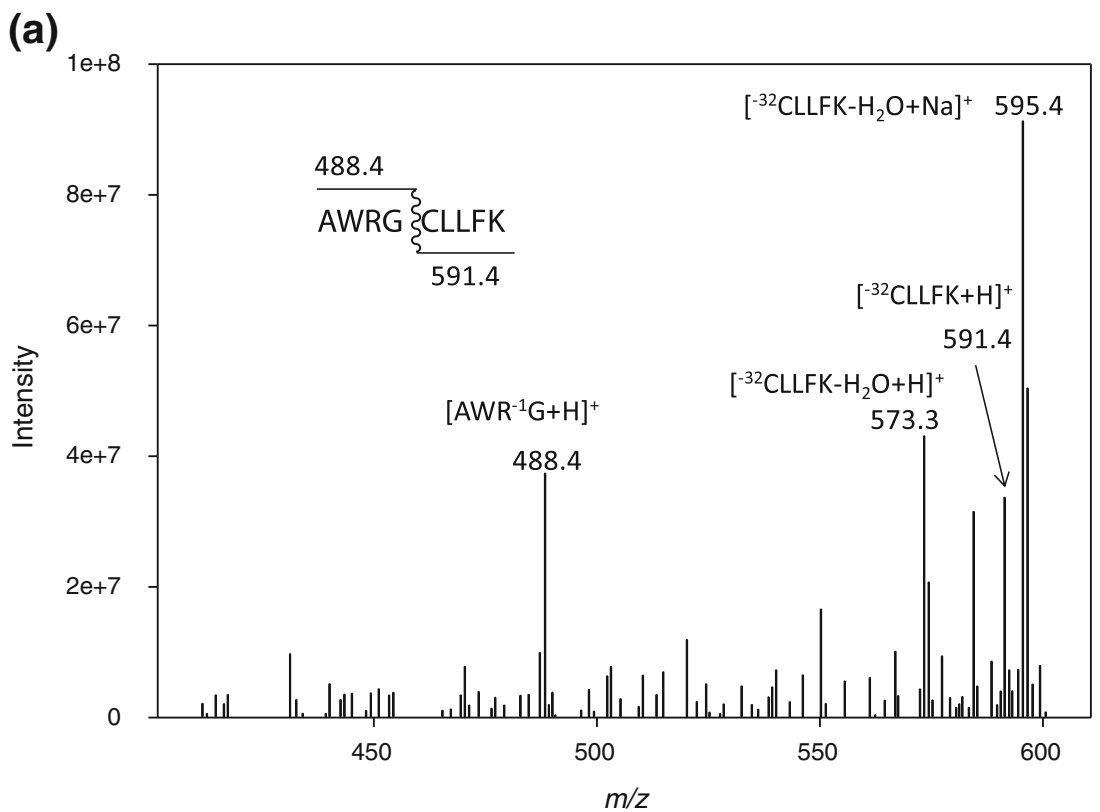

(b)

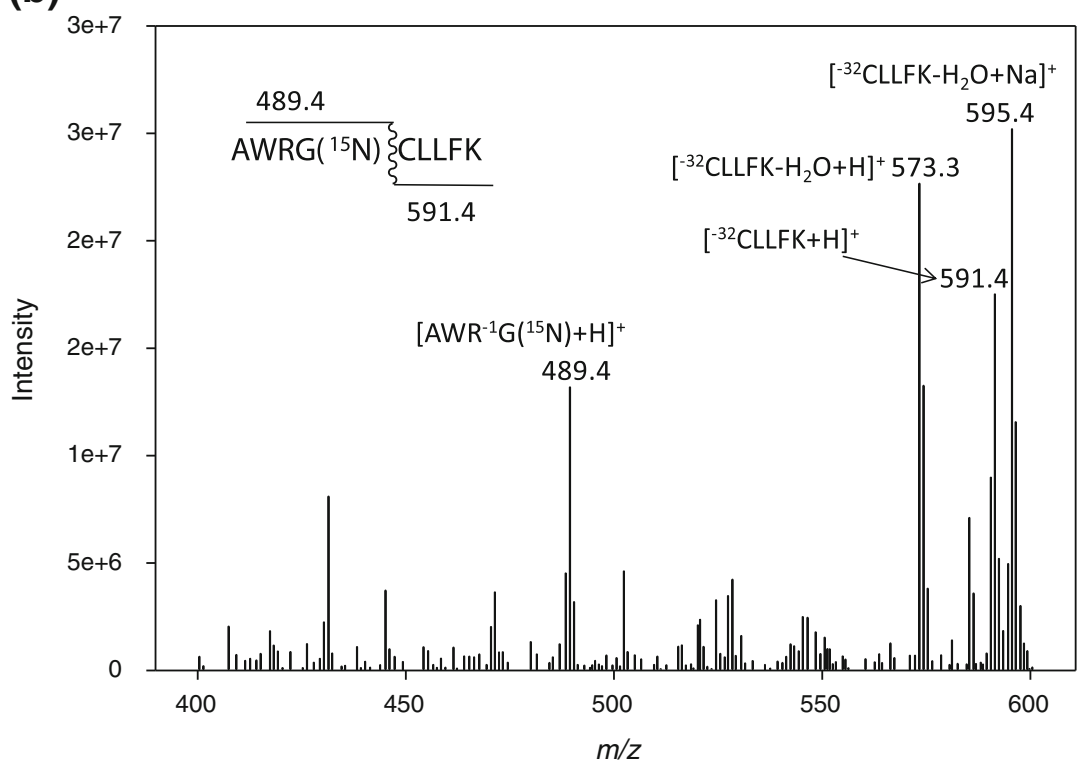

Figure 3. ESI-mass spectra of the nonvolatile thermal decomposition products for the peptide AWRGCLLFK (a) unlabelled and (b) ${ }^{15} \mathrm{~N}-\mathrm{C}_{\mapsto}$ cysteine labeled

consistent with the formation of an amide peptide resulting from the cleavage of the $\mathrm{N}-\mathrm{C}_{\alpha}$ bond on the $\mathrm{N}$-terminus of $\mathrm{C}$ during the thermal decomposition process.

\section{Characterization of the C-Terminal Product of the Thermal Decomposition Cleavage at Cysteine}

The resulting C-terminal product peptide of the thermal decomposition cleavage at $\mathrm{C}$ is characterized by a -32 mass change when compared with a peptide of the same sequence without any modifications. For example, a peptide of the sequence CLLFK would produce a $[\mathrm{M}+\mathrm{H}]^{+}$at $m / z 623.5$, while the observed $[\mathrm{M}+\mathrm{H}]^{+}$of the $\mathrm{C}$-terminal thermal decomposition product, supposedly comprised of the same amino acid sequence, is at $m / z$ 591.5. Evidence acquired via MS/MS measurements of these C-terminal products (Figures $1 \mathrm{~b}$ and $2 \mathrm{c}$ ) point to an $\mathrm{N}$-terminus modification of the peptide with a net mass change of $-32 \mathrm{Da}$. It is also known from our stable isotope studies using ${ }^{15} \mathrm{~N}$ that the nitrogen next to the $\alpha$-carbon is not incorporated into any of the ions corresponding to the C-terminal thermal decomposition products (e.g., $m / z$ 573, 591, and 595 in Figure 3a).

To elucidate the composition of the C-terminal thermal decomposition products, accurate mass measurements of the ion at $\mathrm{m} / \mathrm{z} 505.3$ corresponding to the ${ }^{-32} \mathrm{CKRM}$ peptide thermal decomposition product (see Figure 1a) and the ion at 
(a)

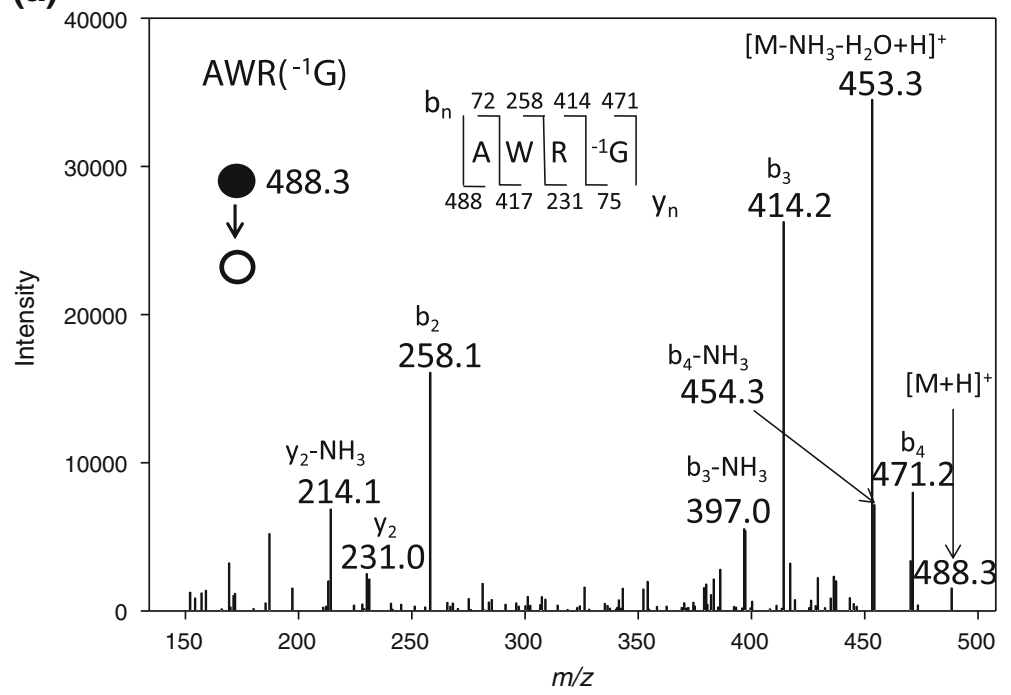

(b)

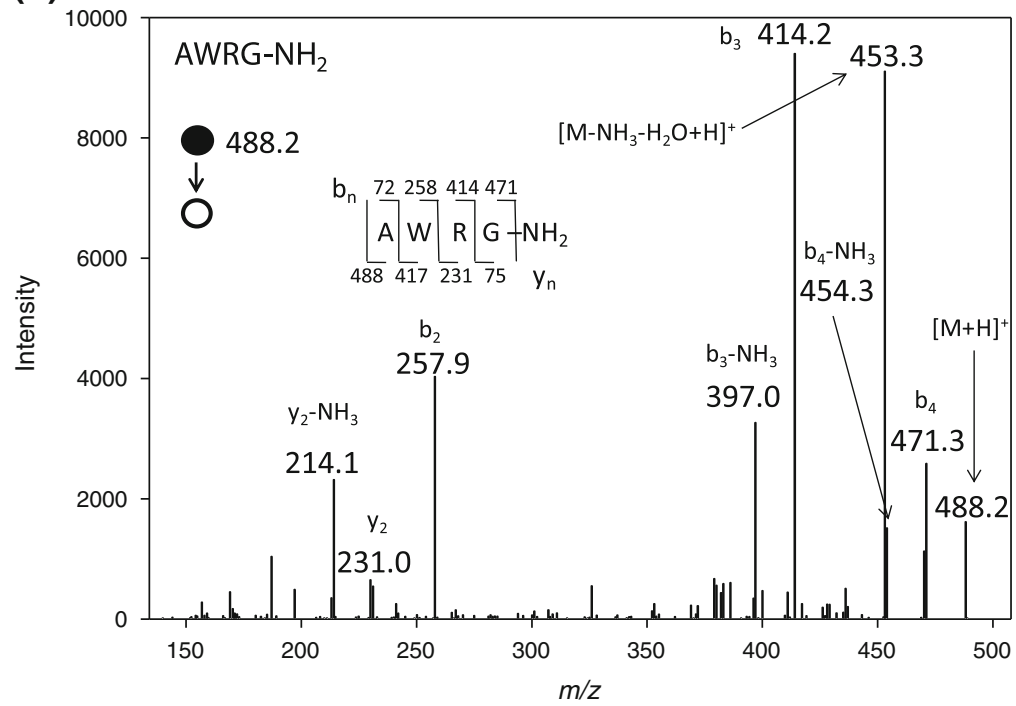

(c)

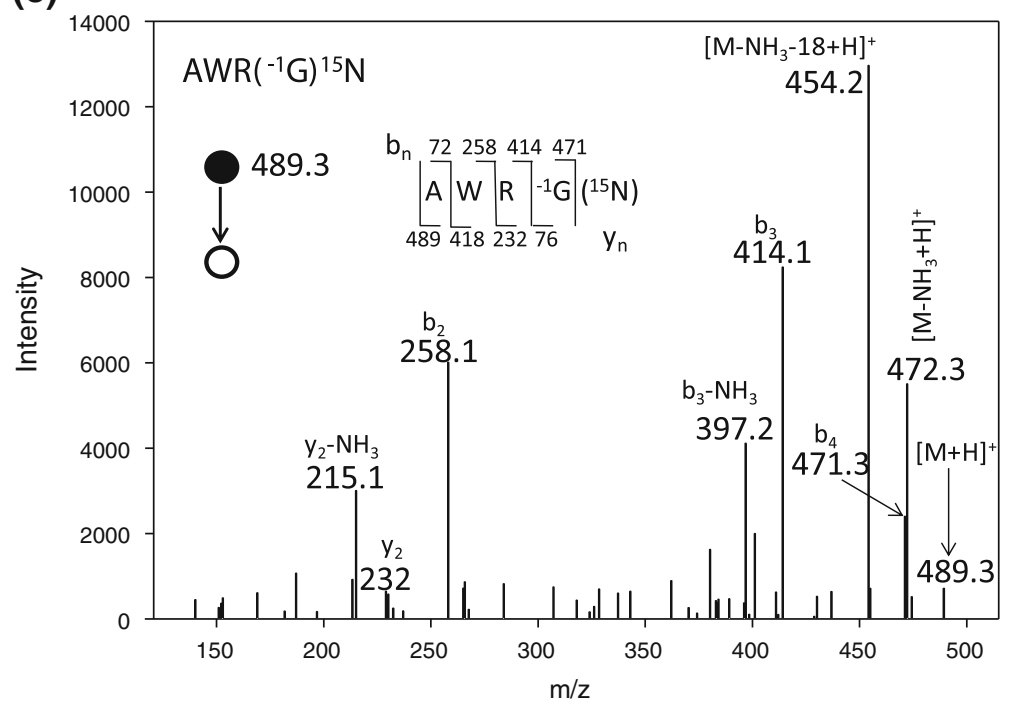

Figure 4. Tandem mass spectra of the AWRG nonvolatile thermal decomposition product of the peptide AWRGCLLFK (a) unlabeled ( $m / z$ 488), (b) an amidated standard peptide (AWRG- $\left.\mathrm{NH}_{2}\right)$, and (c) ${ }^{15} \mathrm{~N}$-labeled $(\mathrm{m} / z$ 489) 
$\mathrm{m} / \mathrm{z} 591.4$ corresponding to the peptide ${ }^{-32}$ CLLFK (see Figure 3a) were performed (the high resolution mass spectrum for the ion at $\mathrm{m} / \mathrm{z} 505.3$ is shown in the Supplementary Material, Figure S-1). The results, listed in Table 1, yielded information about the most likely empirical formula of the N-terminus side of these peptides. The empirical formulae derived from the accurate mass measurements were subtracted from the empirical formula of the section of the peptide assumed to be unmodified, as established by MS/MS measurements shown in Figure 1. For example, the empirical formula for the section of the peptide CLLFK assumed to be unmodified (i.e., LLFK) is $\mathrm{C}_{28} \mathrm{H}_{44} \mathrm{O}_{6} \mathrm{~N}_{5}$, while the accurate mass measurement yielded the empirical formula $\mathrm{C}_{30} \mathrm{H}_{50} \mathrm{O}_{6} \mathrm{~N}_{6}$, leaving an empirical formula balance of $\mathrm{C}_{2} \mathrm{H}_{6} \mathrm{~N}$ for the $\mathrm{N}$-terminus of the peptide. This empirical formula balance is graphically illustrated in Figure S-2 in the Supplementary Material. Accurate mass measurements of two C-terminal thermal decomposition products from two different peptides (PHCKRM and AWRGCLLFK) led to the same empirical formula and the same observed mass change. This empirical formula fits with the formation of either an alanine or $\beta$-alanine $\mathrm{N}$ terminus amino acid for the C-terminal thermal decomposition product peptide.

To gain insight into the mechanism for thermal decomposition cleavage at $\mathrm{C}$, the role of molecular oxygen $\left(\mathrm{O}_{2}\right)$ in the possible initial oxidation of the $\mathrm{C}$ thiol side chain during the thermal decomposition process was investigated. When the thermal decomposition process was performed in an oxygen rich $(\sim 100 \%)$ atmosphere it was found that cleavage product formation was enhanced by a factor of 1.5 when compared with the thermal decomposition process in an air atmosphere (Figure 5). Furthermore, when the thermal decomposition was conducted in a $\mathrm{N}_{2}$ rich $(\sim 100 \%)$ atmosphere, no products resulting from the cleavage at $\mathrm{C}$ were detected, which suggest a direct role for oxygen in the C cleavage.

It is reasonable to assume that at the temperatures used in this study of $220-250{ }^{\circ} \mathrm{C}$ and in the presence of molecular oxygen, initial thiol side chain oxidation to either sulfonic and/or sulfinic acid occurs prior to the $\mathrm{N}-\mathrm{C}_{\alpha}$ bond cleavage. On the other hand, an elimination reaction with a net loss of $\mathrm{H}_{2} \mathrm{~S}$ is not likely to take place under these experimental conditions as they have been observed only at pyrolysis temperatures above $500{ }^{\circ} \mathrm{C}$ [1]. As a result, the mechanism for the thermally induced cleavage at the $\mathrm{N}$-terminus of the cysteine side chain can be rationalized by a loss of the sulfur atom through an initial thiol group oxidation to sulfinic acid
$\left(\mathrm{R}-\mathrm{SO}_{2} \mathrm{H}\right.$, see Scheme 3). With the formation of a cysteine sulfinic acid, the production of an intermediate peptide fragment with a N-terminus dehydroalanine (Dha, ethylene moiety) is believed to take place via a $\mathrm{N}-\mathrm{C}_{\alpha}$ bond cleavage involving a concerted hydrogen abstraction and loss of $\mathrm{SO}_{2}$. Direct evidence for the generation of $\mathrm{SO}_{2}$ during the thermal decomposition of proteins can be found in early studies conducted by Kasarda and Black in 1968 [34], where a sealed glass tube containing a protein sample was heated and connected to an electron ionization (EI)-MS. In their study, they detected volatile thermal decomposition products from protein samples that included $\mathrm{H}_{2} \mathrm{O}, \mathrm{NH}_{3}, \mathrm{CO}_{2}, \mathrm{H}_{2} \mathrm{~S}$, and $\mathrm{SO}_{2}$, with the evolution of $\mathrm{SO}_{2}$ starting at $220{ }^{\circ} \mathrm{C}$ and reaching a maximum intensity at a temperature of $265{ }^{\circ} \mathrm{C}$ (the origin of this $\mathrm{SO}_{2}$ evolution was not known in that study). Under atmospheric conditions and high temperatures the intermediate Dha can undergo either an electrophilic addition (Markonikov orientation) or a free-radical addition (anti-Markonikov addition) with ammonia to yield either an alanine or $\beta$-alanine, respectively, as determined by accurate mass measurements (vide supra). Since the thermal decomposition reactions are being conducted in the condense phase, it is reasonable to assume that the proton source in Scheme 3 can be another acidic group from an adjacent peptide molecule (i.e., an intermolecular acid-base proton transfer). Also in Scheme 3, the thiol side chain in $\mathrm{C}$ can be oxidized to either sulfinic acid $\left(\mathrm{R}-\mathrm{SO}_{2} \mathrm{H}\right)$ or sulfonic acid $\left(\mathrm{R}-\mathrm{SO}_{3} \mathrm{H}\right)$. Experiments conducted with the peptide $\mathrm{PHC}_{\mathrm{ox}} \mathrm{KRM}$, where $\mathrm{C}_{\mathrm{ox}}$ is the $\mathrm{C}$ side chain oxidized to a sulfonic acid did not result in any of the expected nonvolatile products resulting from the cleavage at the $\mathrm{N}$-terminus of $\mathrm{C}$ (data not shown).

The loss of ammonia during the thermal decomposition of peptides containing basic side chains is believed to be one of the sources of ammonia for the final formation of the C-terminus thermal decomposition product. Thermal decomposition experiments conducted in an atmosphere of approximately equimolar amounts of $\mathrm{O}_{2}$ and $\mathrm{NH}_{3}$ gasses (Figure 5) resulted in higher levels of detected products than when performed in air. This last result concurs with the proposed formation of a Dha prior to addition of ammonia (electrophilic and/or free-radical) to form the $\mathrm{C}$-terminus thermal decomposition product. Accordingly, it is expected that the addition of water to the intermediate Dha can also take place to form a corresponding $\mathrm{C}$-terminal thermal decomposition product. A water addition to a Dha would yield a peptide with a hydroxyl group at the $\mathrm{N}$-terminus instead of an amine group. This peptide resulting from the addition of water is expected to have a lower ionization efficiency when analyzed

Table 1. Accurate mass measurements of the C-terminal thermal decomposition (TD) products

\begin{tabular}{|c|c|c|c|c|}
\hline $\begin{array}{l}\text { C-Terminal TD } \\
\text { peptide product }\end{array}$ & Measured M & $\begin{array}{l}\text { Calculated } \\
\text { formula }\end{array}$ & Theor. Mass $(\Delta, \mathrm{ppm})$ & $\begin{array}{l}\text { N-terminus } \\
\text { empirical formula }\end{array}$ \\
\hline${ }_{-32}^{-32}$ CKRM & 504.28358 & $\mathrm{C}_{20} \mathrm{H}_{40} \mathrm{O}_{5} \mathrm{~N}_{8}[32] \mathrm{S}$ & $504.28424(0.01)$ & $\mathrm{C}_{2} \mathrm{H}_{6} \mathrm{~N}$ \\
\hline${ }^{-32}$ CLLFK & 590.37854 & $\mathrm{C}_{30} \mathrm{H}_{50} \mathrm{O}_{6} \mathrm{~N}_{6}$ & $590.37918(0.03)$ & $\mathrm{C}_{2} \mathrm{H}_{6} \mathrm{~N}$ \\
\hline
\end{tabular}




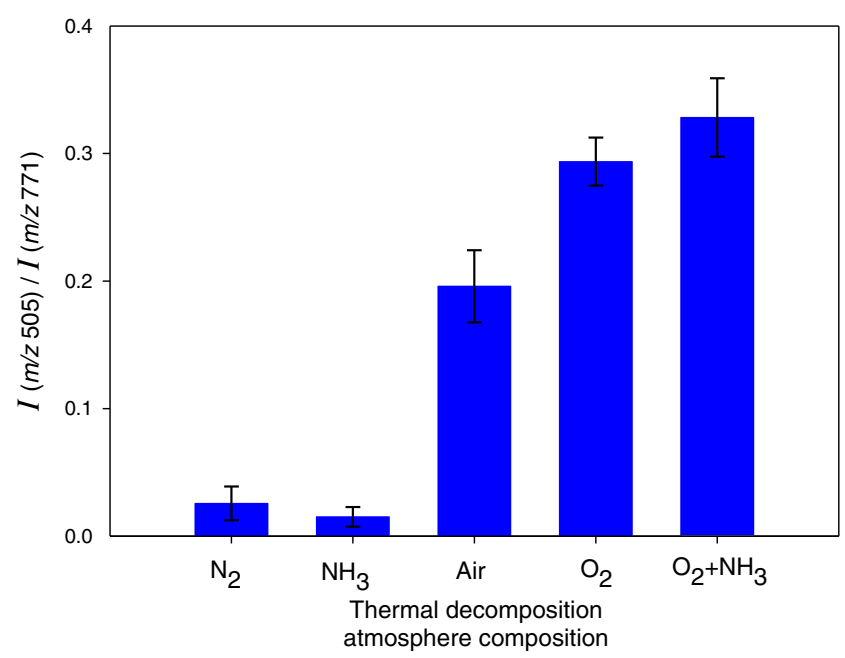

Figure 5. Thermal decomposition (TD) cleavage at $\mathrm{C}$ product ratio under different atmospheres. Product ratio calculated by dividing the peak intensity for the nonvolatile thermal decomposition product peptide $\left({ }^{32} \mathrm{CKRM}\right.$, at $\left.\mathrm{m} / \mathrm{z} 505\right)$ to the intact peptide (PHCKRM), at $m / z$ 771). Error bars represent \pm 1 standard deviation, $n=5$

by ESI than the alanine/ $\beta$-alanine products. Following this rationalization, the presence of the hydroxyl-substituted $\mathrm{N}$ terminal product was confirmed by MS/MS of the ion at $\mathrm{m} / \mathrm{z}$
506, and the resulting tandem mass spectrum was compared with the tandem mass spectrum of the ion at $\mathrm{m} / \mathrm{z} 505$, corresponding to the alanine/ $\beta$-alanine products (Figure $\mathrm{S}-3$, Supplementary Material).

\section{Thermal Degradation/Digestion (TDD) Products of Intact Proteins}

The TDD products of several intact proteins were also characterized in order to assess the method's potential utility as a rapid digestion step for intact proteins. The standard digestion method in bottom-up proteomics often utilizes the enzyme trypsin to induce hydrolysis at the C-terminus of arginine $(\mathrm{R})$ and lysine $(\mathrm{K})$, except when next to a proline residue. It is useful at this stage to compute the expected peptide length when the TDD method is used on several proteins. For a set of $30 \mathrm{E}$. coli proteins (in silico digestion, see Table S-1 in the Supplementary Material for a complete list) the average number of amino acids in a peptide produced by the TDD method is $14( \pm 13)$ amino acids, while digestion with the enzyme trypsin is 9.6 ( $\pm 9.2 ; 1$ standard deviation). Moreover, median values for the peptide length produced by the TDD method is 10 amino acids, while for trypsin digestion is seven amino acids, illustrating that the median value is more representative of the central tendency of these distributions.<smiles>CCCCCC(=O)NC(CS)C(=O)NC(=O)[Te]N</smiles>

Cysteine

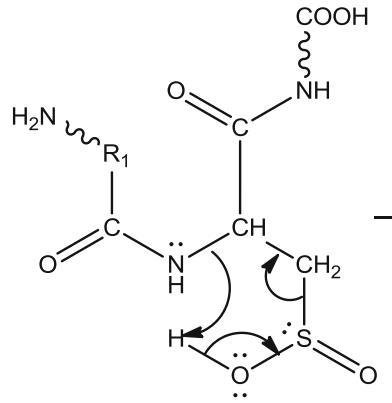

Cysteine sulfinic acid<smiles>C=CC(=O)NC(=O)O[Na]</smiles>

Dehydroalanine (Dha)

$\underline{\text { N-terminal TDD }}$ product<smiles>CC(N)C(=O)N[13C](=O)O</smiles> 
(a)

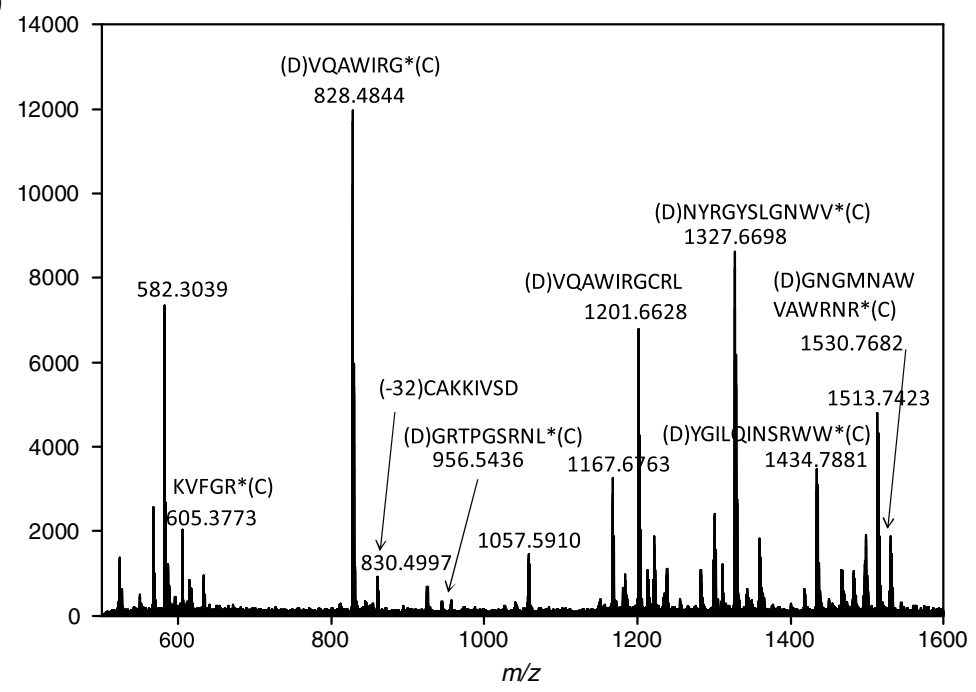

(b)

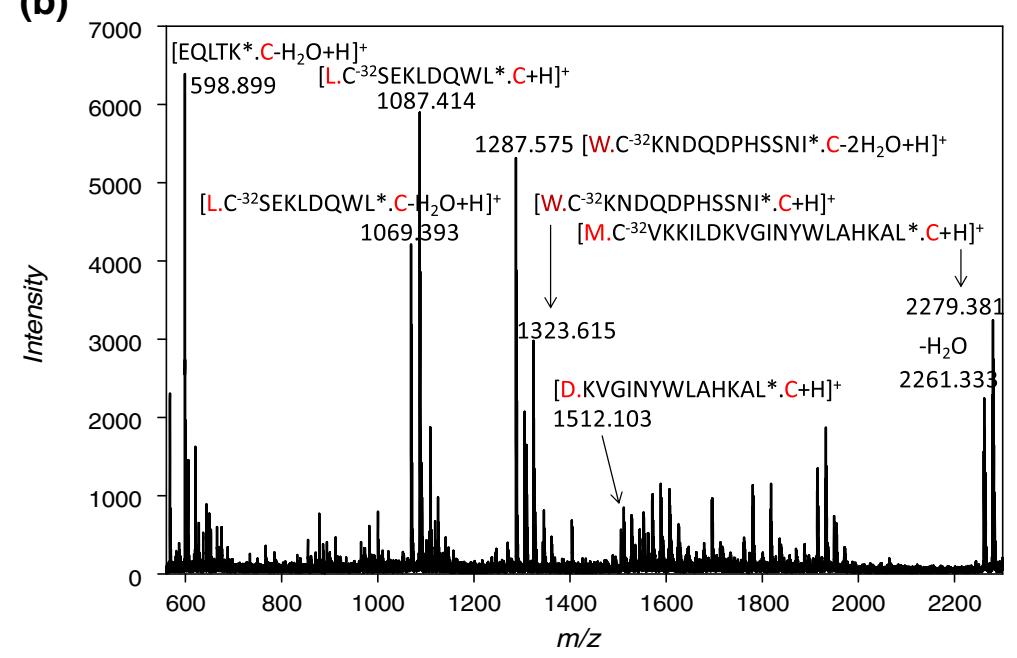

(c)

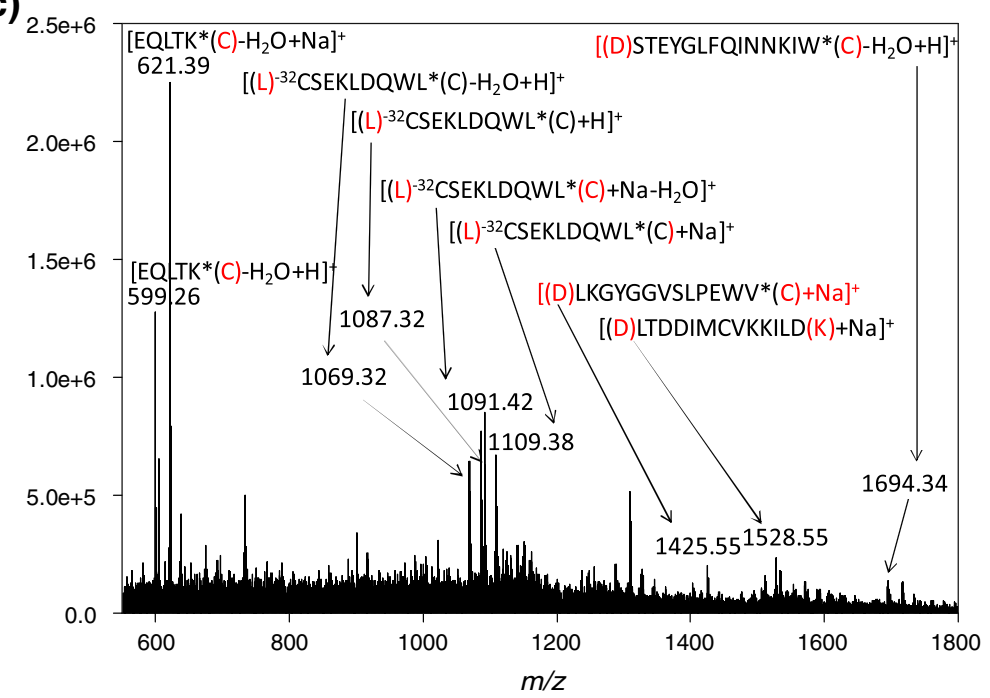

Figure 6. (a) MALDI-mass spectrum of the thermal decomposition products of lysozyme at $220{ }^{\circ} \mathrm{C}$ (MALDI matrix: CHCA; reflectron mode), (b) MALDI-mass spectrum of the thermal decomposition products of $\alpha$-lactalbumin at $220^{\circ} \mathrm{C}$ (MALDI matrix: $\mathrm{CHCA}$; reflectron mode), and (c) ESI-mass spectrum of the thermal decomposition products $\left(220^{\circ} \mathrm{C}\right)$ of a-lactalbumin. Asterisk indicates amidated C-terminus (ESI solvent: 1:1 methanol/0.1\% aqueous formic acid; ESI voltage: $4 \mathrm{kV}$ ) 
Figure S-4 (in Supplementary Material) shows the overall amino acid length distribution expected by the TDD method and compared with trypsin. These length values can be explained by a $12 \%$ combined abundance of $\mathrm{R}$ and $\mathrm{K}$ in proteins, while the combined abundance of $\mathrm{C}$ and $\mathrm{D}$ in proteins is about $7 \%$. Overall, longer peptides can be expected for the TDD method than for a trypsin digest. For example, using data in Figure S-4 the TDD method can potentially generate 41 peptides (out of 659 peptides) with amino acid lengths larger than 40 amino acids, while trypsin digestion of proteins yields only 10 peptides (out of 942 peptides) with 40 or more amino acids.

Mass spectra of the nonvolatile TDD products of two protein standards, lysozyme (chicken, egg white, $14.3 \mathrm{kDa}$ ) and $\alpha$-lactalbumin (bovine, $14.2 \mathrm{kDa}$ ) were obtained and are shown in Figure 6. The MALDI-mass spectra of the nonvolatile pyrolysis products of these proteins vary in terms of number of peptides detected and protein sequence coverage, reflecting both the sequence-specific nature of the TDD process and possible suppression ionization effects common in the MS analysis of peptide mixtures, as no LC step was performed in this study. For the protein lysozyme, the MALDI-mass spectrum in Figure 6a features a wide range of peptide products stemming from both cleavages at the $\mathrm{C}$-terminus of $\mathrm{D}$ and at the $\mathrm{N}$-terminus of $\mathrm{C}$. For example, the peptide detected at $m / z 828.484$ (VQAWIRG-NH ${ }_{2}$, calculated $\mathrm{MH}^{+}$monoisotopic mass $828.469 \mathrm{Da}$ ) was the result of a combined thermal cleavage at the C-terminus of D (D-119 in the sequence, see protein sequence in the Supplementary Material) and N-terminus of $\mathrm{C}$ (C-127 in the sequence), the latter leading to the amidation of the $\mathrm{C}$-terminus $\mathrm{G}$. Also, the peptide detected at $m / z 1201.663$ corresponds to the $\mathrm{C}$-terminus end of the protein (cleavage at D-119) and shows a missed cleavage at $\mathrm{C}$ (C-127) [2]. This same peptide with two consecutive ammonia losses (two $\mathrm{R}$ groups in its sequence) is also detected at $\mathrm{m} / \mathrm{z}$ 1167.676. Sequence confirmation of the ions at $\mathrm{m} / \mathrm{z} 605.37,828.48,1327.67$, and 1434.79 observed in Figure 6a was performed by ESI-MS/MS and their corresponding tandem mass spectra are shown in the Supplementary Material, Figures S-5, S-6, S-7, and S-8. Overall, a protein sequence coverage of $52 \%$ was obtained for lysozyme. Worth noting is the fact that there are several disulfide bonds within lysozyme and that these must have been broken during the TDD process in order to observe the peptides present in the mass spectrum in Figure 6a. For example, disulfide bonds must be broken in order to generate the observed peptide fragments of sequences $\mathrm{KVFGR}^{*}(\mathrm{C})\left(\mathrm{MH}^{+}\right.$at $\mathrm{m} / \mathrm{z}$ 605.378; asterisk indicates amidated C-terminus), (D)NYRGYSLGNWV*(C) $\left(\mathrm{MH}^{+}\right.$at $m / z$ 1327.770), (D)YGILQINSRWW*(C) $\left(\mathrm{MH}^{+}\right.$ at $\mathrm{m} / \mathrm{z}$ 1434.788), (D)GRTPGSRNL*(C) $\left(\mathrm{MH}^{+}\right.$at $\mathrm{m} / \mathrm{z}$ 956.544), (D)VQAWIRGCRL $\left(\mathrm{MH}^{+}\right.$at $\mathrm{m} / \mathrm{z}$ 1201.663), and (D)VQAWIRG*(C) $\left(\mathrm{MH}^{+}\right.$at $\mathrm{m} / \mathrm{z}$ 828.484). The detection of these peptides provides preliminary evidence that disulfide bonds are broken in lysozyme during the TDD process; however, further work is currently under way to confirm and elucidate this disulfide bond fragmentation mechanism.

The TDD products of the protein $\alpha$-lactalbumin were analyzed by both MALDI-MS and ESI-MS (the same sample was split and analyzed by both techniques) and their mass spectra are shown in Figure $6 \mathrm{~b}$ and c, respectively. The MALDI-mass spectrum in Figure $6 \mathrm{~b}$ shows signals of peptide products resulting from thermally induced cleavages at both $\mathrm{D}$ and $\mathrm{C}$ amino acids, in addition to peptides corresponding to dehydration products, most likely due to water loss from acidic groups like D and E. Figure $6 \mathrm{c}$ shows the ESI-mass spectrum of the TDD products of the protein $\alpha$-lactalbumin, where several ions observed in the MALDImass spectrum in Figure $6 \mathrm{~b}$ are also present, mainly ions at $\mathrm{m} / \mathrm{z}$ 599.26, 1069.32, and 1087.32. In addition, several peptides were only detected by either MS analysis, illustrating the complementary nature between MALDI and ESI. Sequence confirmation of the ions at $\mathrm{m} / z$ 599, 1087, and 1693 was performed by ESI-MS/MS and their corresponding tandem mass spectra are shown in the Supplementary Material, Figures S-9, S-10, and S-11. With the combined results from the MALDI and ESI-MS measurements in Figure $6 \mathrm{~b}$ and $\mathrm{c}$, a sequence coverage of $64 \%$ is obtained for $\alpha$-lactalbumin using the TDD method. Table 2 lists all the peptides detected from the TDD of $\alpha$-lactalbumin by MALDI-MS and/or ESI-MS. It is expected that higher

Table 2. Peptides detected by either MALDI and/or ESI-MS from the TDD of the protein $\alpha$-lactalbumin (peptides cleaved at C have an amidated C-terminus)

\begin{tabular}{|c|c|c|c|c|}
\hline Peptide sequence & Ion & $m / z$ (nominal) & ESI & MALDI \\
\hline EQLTK(C) & {$\left[\mathrm{M}-\mathrm{H}_{2} \mathrm{O}+\mathrm{H}\right]^{+}$} & 599 & $\mathrm{X}$ & $\mathrm{X}$ \\
\hline EQLTK(C) & {$\left[\mathrm{M}-\mathrm{H}_{2} \mathrm{O}+\mathrm{Na}\right]^{+}$} & 621 & $\mathrm{X}$ & \\
\hline$(\mathrm{L})^{-32}$ CSEKLDQWL(C) & {$[\mathrm{M}+\mathrm{H}]^{+}$} & 1087 & $\mathrm{X}$ & $\mathrm{X}$ \\
\hline$(\mathrm{L})^{-32} \mathrm{CSEKLDQWL}(\mathrm{C})$ & {$\left[\mathrm{M}-\mathrm{H}_{2} \mathrm{O}+\mathrm{H}\right]^{+}$} & 1069 & $\mathrm{X}$ & $\mathrm{X}$ \\
\hline$(\mathrm{L})^{-32}$ CSEKLDQWL(C) & {$\left[\mathrm{M}-\mathrm{H}_{2} \mathrm{O}+\mathrm{Na}\right]^{+}$} & 1091 & $\mathrm{X}$ & $\mathrm{X}$ \\
\hline$(\mathrm{W})^{-32} \mathrm{CKNDQDPHSSNI}(\mathrm{C})$ & {$[\mathrm{M}+\mathrm{H}]^{+}$} & 1324 & & $\mathrm{X}$ \\
\hline (W) ${ }^{-32}$ CKNDQDPHSSNI(C) & {$\left[\mathrm{M}-2 \mathrm{H}_{2} \mathrm{O}+\mathrm{H}\right]^{+}$} & 1288 & & $\mathrm{X}$ \\
\hline (D)LKGYGGVSLPEWV(C) & {$[\mathrm{M}+\mathrm{Na}]^{+}$} & 1426 & $\mathrm{X}$ & \\
\hline (D)KVGINYWLAHKAL(C) & {$[\mathrm{M}+\mathrm{H}]^{+}$} & 1512 & & $\mathrm{X}$ \\
\hline (D)LTDDIMCVKKILD(K) & {$[\mathrm{M}+\mathrm{Na}]^{+}$} & 1529 & $\mathrm{X}$ & \\
\hline (D)STEYGLFQINNKIW(C) & {$\left[\mathrm{M}-\mathrm{H}_{2} \mathrm{O}+\mathrm{H}\right]^{+}$} & 1694 & $\mathrm{X}$ & \\
\hline (M) ${ }^{-32}$ CVKKILDKVGINYWLAHKAL(C) & {$[\mathrm{M}+\mathrm{H}]^{+}$} & 2279 & & $\mathrm{X}$ \\
\hline (M) ${ }^{-32}$ CVKKILDKVGINYWLAHKAL(C) & {$\left[\mathrm{M}-\mathrm{H}_{2} \mathrm{O}+\mathrm{H}\right]^{+}$} & 2261 & & $\mathrm{X}$ \\
\hline
\end{tabular}


sequence coverages would be possible by incorporation of a LC step prior to ESI-MS.

\section{Conclusions}

Conclusive evidence was presented for the thermally induced site-specific cleavage at the $\mathrm{N}$-terminus of the amino acid $\mathrm{C}$ in peptides and proteins. Also demonstrated in this work was the simultaneous cleavage at $\mathrm{D}$ and $\mathrm{C}$ under the same experimental conditions in protein standards. Mass spectrometry studies combining a peptide containing a ${ }^{15} \mathrm{~N}$ stable isotope, peptides with oxidized $\mathrm{C}, \mathrm{MS} / \mathrm{MS}$, and accurate mass measurements of the TDD products revealed a cleavage at the $\mathrm{N}$-terminus of $\mathrm{C}$. Studies showed that this thermally induced cleavage at $\mathrm{C}$ most likely involves an initial thiol group oxidation to sulfinic acid, and thus requires the presence of molecular oxygen (i.e., performed under atmospheric conditions). The cleavage at the $\mathrm{N}$-terminus of $\mathrm{C}$ proceeds by a concerted $\mathrm{N}-\mathrm{C}_{\alpha}$ bond cleavage and loss of $\mathrm{SO}_{2}$, forming an intermediate $\mathrm{Dha}$ at the $\mathrm{N}$-terminus of the C-terminal TDD product. Addition of ammonia (or water) to this Dha moiety is believed to be the final step in the formation of either an alanine and/or $\beta$-alanine $\mathrm{C}$-terminal TDD product. Tandem MS measurements of the $\mathrm{C}$ - and $\mathrm{N}$-terminal TDD products of peptide and protein standards showed preserved information of the direct amino acid sequence, pointing to the chemical site-specificity of the method and its compatibility with MS detection. Evidence from the analysis of proteins with TDD presented in this study also showed that disulfide bonds are cleaved during this process, and further work is currently under way to elucidate the disulfide bond fragmentation mechanism by TDD. Given the TDD method speed (10 s), reagentless nature, site-specificity and the moderate length of the peptides produced, current work in our laboratory is exploring the utility of the TDD method as part of a proteomic workflow for rapid protein identification.

\section{Acknowledgments}

The authors acknowledge the National Science Foundation (NSF-CAREER CHE-0844694) and the National Institutes of Health (NIH-AREA R15 RR020354-01A1) for their financial support of this work. The authors are also grateful to Dr. Jan Kubelka's research group at the University of Wyoming for their assistance in the synthesis of a model peptide used in this study. Thanks also to Dr. Krishna Parsawar at the University of Utah Mass Spectrometry and Proteomics Core Facility for FTMS accurate-mass measurements.

\section{References}

1. Moldoveanu S. C.: Pyrolysis of Organic Molecules with Applications to Health and Environmental Issues Vol. 28; Elsevier: Amsterdam, (2010)

2. Zhang S., Basile, F.: Site-specific pyrolysis-induced cleavage at aspartic acid residue in peptides and proteins. J. Proteome Res. 6, 1700-1704 (2007)
3. Hacaloglu J., Yalcin, T., Oenal, A. M.: Pyrolysis studies to investigate effects of polymerization techniques on structure and thermal behavior of poly(1,2-epoxy-4-epoxyethylcyclohexanes). J. Macro. Sci. Pure Appl. Chem. A32, 1167-1181 (1995)

4. Blazso M.: Recent trends in analytical and applied pyrolysis of polymers. J. Anal. Appl. Pyrolysis 39, 1-25 (1997)

5. Posthumus M. A., Boerboom, A. J. H., Meuzelaar, H. L. C.: Analysis of biopolymers by Curie-point pyrolysis in direct combination with lowvoltage electron impact ionization mass spectrometry. Advances Mass Spectrom. 6, 397-402 (1974)

6. Ballistreri A., Giuffrida, M., Maravigna, P., Montaudo, G.: Direct mass spectrometry of polymers. XII. Thermal fragmentation processes in poly (a-amino acids). J. Polym. Sci. Part A Polym. Chem. 23, 1145-1161 (1985)

7. Anhalt J. P., Fenselau, C.: Identification of bacteria using mass spectrometry. Anal. Chem. 47, 219-225 (1975)

8. Beverly M. B., Basile, F.,Voorhees, K. J., Hadfield, T. L.: A rapid approach for the detection of di-picolinic acid in bacterial spores using pyrolysis/mass spectrometry. Rapid Commun. Mass Spectrom. 10, 455458 (1996)

9. Wieten G., Meuzelaar, H. L. C., Haverkamp, J.: Analytical pyrolysis in clinical and pharmaceutical microbiology. In Odham, G.; Larsson, L.; Maardh, P.-A., (eds.) Gas Chromatogr./Mass Spectrom. Appl. Microbiol, pp 335-380. Plenum, (1984)

10. Dworzanski J. P., Tripathi, A., Snyder, A. P., Maswdeh, W. M., Wick, C. H.: Novel biomarkers for gram-type differentiation of bacteria by pyrolysis-gas chromatography-mass spectrometry. J. Anal. Appl. Pyrolysis 73, 29-38 (2005)

11. Voorhees K. J., Durfee, S. L., Updegraff, D. M.: Identification of diverse bacteria grown under diverse conditions using pyrolysis-mass spectrometry. J. Microbiol. Methods 8, 315-325 (1988)

12. DeLuca S., Sarver, E. W., Harrington, P. d. B., Voorhees, K. J.: Direct analysis of bacterial fatty acids by Curie-point pyrolysis tandem mass spectrometry. Anal. Chem. 62, 1465-1472 (1990)

13. Basile F., Beverly, M. B., Abbas-Hawks, C., Mowry, C. D.,Voorhees, K. J., Hadfield, T. L.: Direct mass spectrometric analysis of in situ thermally hydrolyzed and methylated lipids from whole bacterial cells. Anal. Chem. 70, 1555-1562 (1998)

14. Fenn J. B., Mann, M., Meng, C. K., Wong, S. F., Whitehouse, C. M.: Electrospray ionization for mass spectrometry of large biomolecules. Science 246, 64-71. (1989)

15. Fenn J. B., Mann, M., Meng, C. K., Wong, S. F., Whitehouse, C. M.: Electrospray ionization - principles and practice. Mass Spectrom. Rev. 9, 37-70 (1990)

16. Kebarle P.,Verkerk, U.: On the mechanism of electrospray ionization mass spectrometry (ESIMS). In: Cole, R. B., (ed.) Electrospray and MALDI Mass Spectrometry, 2nd ed., pp 3-48. John Wiley and Sons, Inc. (2010)

17. Karas M., Bachmann, D., Hillenkamp, F.: Influence of the wavelength in high-irradiance ultraviolet laser desorption mass spectrometry of organic molecules. Anal. Chem. 57, 2935-2939 (1985)

18. Karas M., Hillenkamp, F.: Laser desorption ionization of proteins with molecular masses exceeding 10,000 daltons. Anal. Chem. 60, 22992301 (1988)

19. Karas M., Bahr, U., Ingendoh, A., Hillenkamp, F.: Laser-desorption mass spectrometry of 100,000-250,000 Da proteins. Angew. Chem. 101, 805-806 (1989)

20. Knochenmuss R.: MALDI ionization mechanisms: an overview. In Electrospray and MALDI Mass Spectrometry 2nd ed., pp 149-183. John Wiley and Sons, Inc. (2010)

21. Lattimer R. P., Polce, M. J., Wesdemiotis, C.: MALDI-MS analysis of pyrolysis products from a segmented polyurethane. J. Anal. Appl. Pyrolysis 48, 1-15 (1998)

22. Lattimer R. P.: Mass spectral analysis of low-temperature pyrolysis products from poly(ethylene glycol). J. Anal. Appl. Pyrolysis 56, 61-78 (2000)

23. Meetani M. A., Basile, F.,Voorhees, K. J.: Investigation of pyrolysis residues of poly(amino acids) using matrix assisted laser desorption ionization-time of flight-mass spectrometry. J. Anal. Appl. Pyrolysis 68/ 69, 101-113 (2003)

24. Meetani M. A., Zahid, O. K., Michael Colon, J. M.: Investigation of the pyrolysis products of methionine-enkephalin-Arg-Gly-Leu using liquid chromatography tandem mass spectrometry. J. Mass Spectrom. 45, 1320-1331 (2010) 
25. Zhang S., Shin, Y.-S., Mayer, R., Basile, F.: On-probe pyrolysis desorption electrospray ionization (DESI) mass spectrometry for the analysis of nonvolatile pyrolysis products. J. Anal. Appl. Pyrolysis $\mathbf{8 0}$, 353-359 (2007)

26. Chen X., Yu, L., Steill, J. D., Oomens, J., Polfer, N. C.: Effect of peptide fragment size on the propensity of cyclization in collisioninduced dissociation: Oligoglycine b2-b8. J. Am. Chem. Soc. 131, 18272-18282 (2009)

27. Molesworth S., Osburn, S., Van Stipdonk, M.: Influence of size on apparent scrambling of sequence during CID of b-type ions. J. Am. Soc. Mass Spectrom. 20, 2174-2181 (2009)

28. Chen, X., Steill, J. D., Oomens, J., Polfer, N. C.: Oxazolone versus macrocycle structures for Leu-enkephalin b2-b4: insights from infrared multiple-photon dissociation spectroscopy and gas-phase hydrogen/deuterium exchange. J. Am. Soc. Mass Spectrom. 21, 1313-1321 (2010)
29. Gucinski, A. C., Somogyi, A., Chamot-Rooke, J.,Wysocki, V. H.: Separation and identification of structural isomers by quadrupole collision-induced dissociation-hydrogen/deuterium exchange-infrared multiphoton dissociation (QCID-HDX-IRMPD). J. Am. Soc. Mass Spectrom. 21, 1329-1338 (2010)

30. Bythell B. J., Knapp-Mohammady, M., Paizs, B., Harrison, A. G.: Effect of the His Residue on the Cyclization of b Ions. J. Am. Soc. Mass Spectrom. 21, 1352-1363 (2010)

31. ABRF Delta Mass: A Database of Protein Post Translational Modifications. http://www.abrf.org/index.cfm/dm.home?AvgMass=all; accessed on November 10, (2010)

32. Paizs B., Suhai, S.: Fragmentation pathways of protonated peptides. Mass Spectrom. Rev. 24, 508-548 (2005)

33. Ballard K. D., Gaskell, S. J.: Dehydration of peptide $[\mathrm{M}+\mathrm{H}]+$ ions in the gas phase. J. Am. Soc. Mass Spectrom. 4, 477-481 (1993)

34. Kasarda D. D., Black D. R.: Thermal degradation of proteins studied by mass spectrometry. Biopolymers 6, 1001-1004 (1968) 